\title{
Spatial and temporal dynamics of suspended particles and E. coli in a complex surface-water and karst groundwater system as a basis for an adapted water protection scheme, northern Vietnam
}

\author{
Dominik Richter $^{1} \cdot$ Nadine Goeppert $^{1} \cdot$ Björn Zindler $^{2} \cdot$ Nico Goldscheider ${ }^{1}$
}

Received: 25 August 2020 / Accepted: 26 April 2021 / Published online: 28 May 2021

(C) The Author(s) 2021

\begin{abstract}
Karst aquifers in subtropical regions are characterized by high variability of water availability and quality due to changes associated with rainy and dry seasons. An additional challenge for water management is the combination of surface-water and karst groundwater systems since high spatiotemporal dynamics cause high variability of water quality. In these cases, adapted protection strategies are required. In this study, a protection approach for the catchment of a river-water diversion point in a rural area in northern Vietnam is developed. The variability of water quality was evaluated by rainy and dry season synoptic surveys of suspended particles and microbial contamination at 49 sites and time series at three sets of paired sites under constant hydraulic conditions. The anthropogenic land-use activities in the catchment were mapped to identify potential contamination sources and to highlight the challenging combination of surface-water and karst groundwater management. The analyzed data indicate differences in water quality between the dry and rainy seasons and a higher influence on water quality from land use than from hydrologic conditions. Furthermore, the results suggest a high risk of contamination resulting from residential areas, agriculture, and livestock farming, and reveal the necessity of implementation of appropriate measures such as restricted farming and the hook-up of buildings to municipal sewage disposal. Finally, the data show that water quality can be improved by adjusting water withdrawals by the time of day. The applied methods can be transferred to other surface-water and karst groundwater systems in similar subtropical environments.
\end{abstract}

Keywords Particles $\cdot$ Water-quality monitoring $\cdot$ Land use $\cdot$ Karst $\cdot$ Vietnam

Dominik Richter

dominik.richter@kit.edu

Nadine Goeppert

nadine.goeppert@kit.edu

Björn Zindler

bjoern.zindler@rub.de

Nico Goldscheider

nico.goldscheider@kit.edu

1 Division of Hydrogeology, Karlsruhe Institute of Technology (KIT), Institute of Applied Geosciences, Kaiserstr. 12,

76131 Karlsruhe, Germany

2 Institute of Environmental Engineering and Ecology (eE+E), Ruhr University Bochum (RUB), Universitätsstr. 150,

44780 Bochum, Germany

\section{Introduction}

Asia is the continent with the largest absolute surface area underlain by carbonate rocks. In Vietnam, carbonate rocks are present over an area of $99,300 \mathrm{~km}^{2}$; more than a quarter of the total area of the country (Goldscheider et al. 2020). These carbonates formed during the Early Cambrian to Late Cretaceous (Tran et al. 2013; Van Nguyen et al. 2013). Dissolution processes, assisted by the subtropical climate, created a karst terrain characterized by sinking streams, caves, enclosed depressions, fluted rock outcrops, and large springs (Ford and Williams 2013).

Due to rapid percolation and concentrated infiltration through swallow holes, the filtration capacities of karst aquifers are weak. Karst aquifers, therefore, are highly vulnerable to pollutants. This vulnerability is intensified by high flow velocities in fissures and conduits, short residence times, and high hydraulic and hydrochemical variability after rain events (e.g. Pronk et al. 2007; Ford and Williams 2013; Jiang et al. 
2015). Low- to middle-income countries, including Vietnam, are facing major concerns with water resource management in karst areas due to inadequate water supply, lack of source protection, and lack of wastewater disposal and treatment (Ender 2018). One of the main problems is fecal contamination of the water caused by human settlements, farming, and livestock, leading to a widespread occurrence of waterborne diseases (Montgomery and Elimelech 2007). Nguyet and Goldscheider (2006a) found that poor microbial water quality is a common problem for subtropical Vietnamese karst regions, and poses a threat to human health as locals are dependent on the use of the poor-quality water sources. The analysis of fecal indicator bacteria (FIB) is commonly used to assess the hygienic quality of water. Analysis of total coliforms (TC), fecal coliforms (FC), Escherichia coli (E. coli), and enterococci are well-established indicators. As $E$. coli has the highest sanitary significance, while TC and FC can partly originate from nonfecal sources and overestimate pollution (Cabral and Marques 2006; Doyle and Erickson 2006), E. coli is used for this study as the indicator for fecal contamination. To determine the presence of $E$. coli, standard culture-based techniques with incubation times between 18 and $24 \mathrm{~h}$ are commonly used. In remote areas, insufficient technical infrastructure and the time required for analyses often make it impossible to prevent contaminated water from entering the distribution system.

Suspended particles play an important role in the transport of pollutants because bacteria tend to adhere to particles (Dussart-Baptista et al. 2003; Pronk et al. 2006; Schillinger and Gannon 1985). In contrast, free-floating bacteria are less persistent within the aquatic environment. In karst aquifers, particulate substances are transported over long distances in short times and are influenced by processes such as sedimentation and remobilization. Due to the attachment of $E$. coli to a mobile solid phase, they are strongly influenced by these hydrodynamic processes (Mahler et al. 2000; Goldscheider et al. 2010). Several studies have established particle concentration as an indicator of microbial pollution (Mahler et al. 2004; Pronk et al. 2007). To date, only a few studies measure particle concentration in-situ with a high temporal resolution, despite this being crucial for measurement accuracy and reliability (Wilkinson and Lead 2007). Previous studies mainly deal with the concentration of suspended particles at springs (e.g. Schiperski et al. 2015); only a few studies take into account the system's input (swallow hole) (Pronk et al. 2007; Fournier et al. 2008; Goeppert and Goldscheider 2019).

The full range of factors influencing water quality in a complex surface water and groundwater systemcontamination potentials, transport processes of pollutants, cave systems, hydraulic conditions, and daytime - has to be considered in its entirety. Especially in karst systems with high flow velocities and low filtration, it is crucial to take into account a comprehensive perspective and to use data with high temporal resolutions when assessing water quality in terms of sediment-contaminant interaction. High temporal resolution time series have so far primarily been event-based, collected during and after precipitation events or snowmelt (Pronk et al. 2009; Schiperski et al. 2015). In addition to hydro-meteorological parameters, local land-use practices (farming, sewage disposal) can have a major impact on water quality. Therefore, detailed time series under constant discharge conditions can be a valuable tool for the assessment of water quality - for example, Grimmeisen et al. (2016) were able to identify the impact of leakages in an intermittent water supply system on urban groundwater by high-resolution monitoring.

In order to consider an appropriate and suitable number of local factors influencing water quality, the following methods were combined in this study: measurements across the catchment at high and low flow conditions; high temporal resolution simultaneous sampling with in-situ measurements under constant hydraulic conditions at selected paired sites; and GIS analyses of the anthropogenic land use in the catchment to highlight the contamination potentials for the water resources.

This study aims to (1) characterize seasonal fluctuations in water quality at karst springs, nonkarst springs, cave streams, and surface streams in a complex surface and karst groundwater system, (2) identify variations of water quality at springskarst and nonkarst — and in a surface stream under constant discharge conditions, and (3) develop the basis for a pragmatic protection scheme based on a GIS analysis of the land use.

\section{Materials and methods}

\section{Study site}

The city of Dong Van is located in the northernmost Vietnamese province Ha Giang, close to the Chinese border (Fig. 1a). This remote region faces problems regarding water availability and quality due to the influence of a subtropical climate with extended rainy and dry seasons. Since the 2010 UNESCO designation of the "Dong Van Karst Plateau" as a Global Geopark, the number of tourists in the region has risen sharply, and the water demand is increasing accordingly, which puts more pressure on the already stressed water supply situation (Zindler and Stolpe 2018). To meet this additional water demand and to prevent shortages for the mountain villages of the local minorities, a new water supply has been built (Oberle et al. 2018; Walter 2020). To protect the water resources against contamination and overexploitation, a profound understanding of the local hydrogeological conditions is essential.

The water used to supply the region originates from springs in the catchment of the Ma Le River, which sinks underground via a swallow hole at the southeastern end of the valley into a 

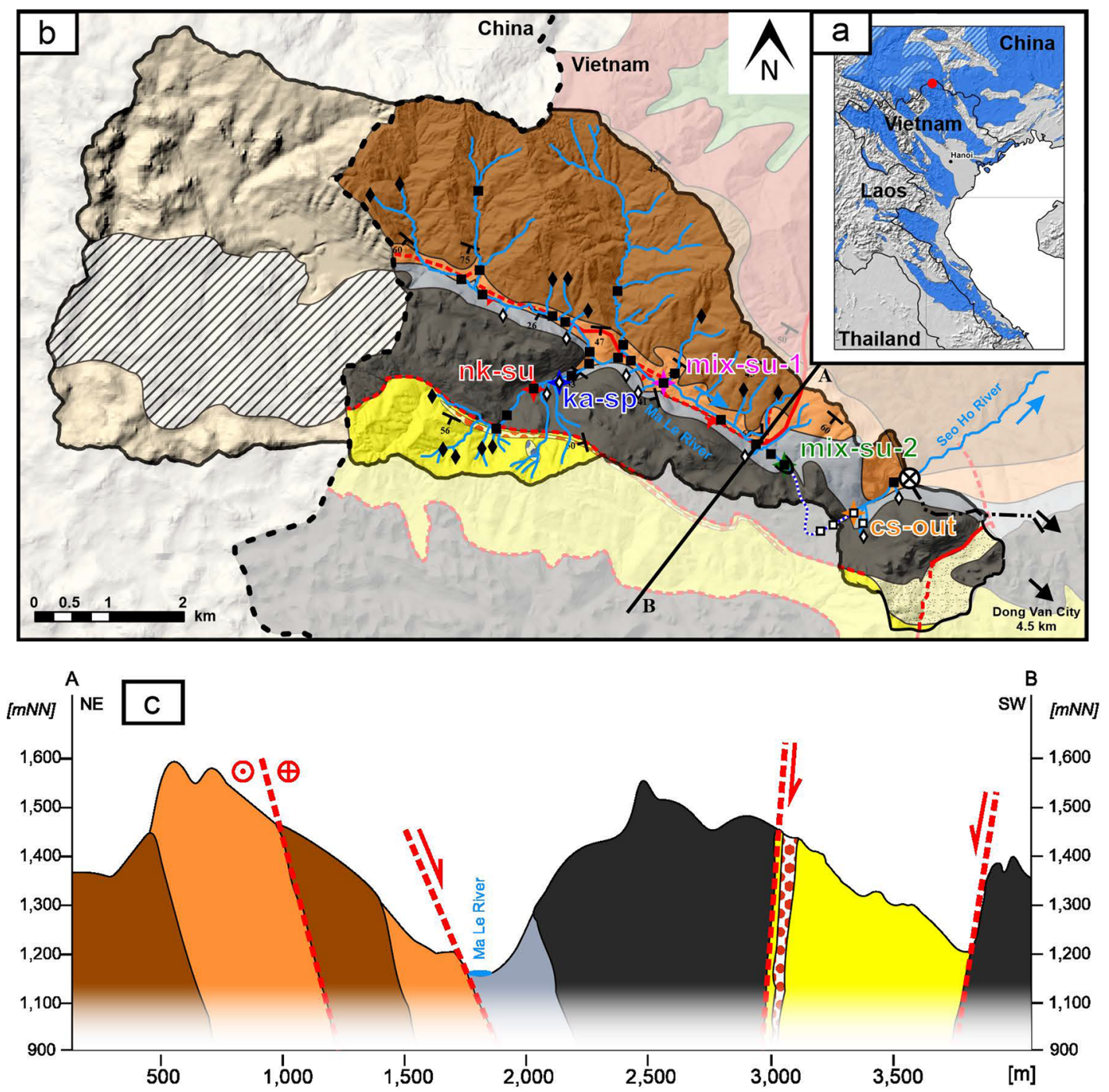

\section{Legend:}
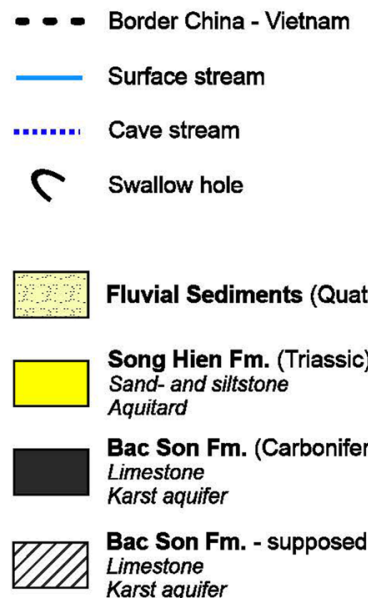

Fluvial Sediments (Quaternary)

Song Hien Fm. (Triassic)

Sand- and siltstone

Aquitard

Bac Son Fm. (Carboniferouse-Permian)

Limestone

Karst aquifer

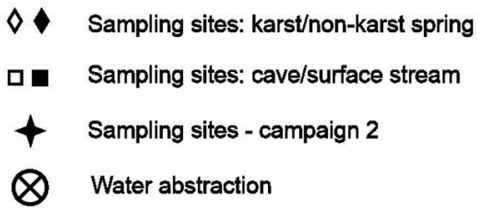

Bac Son Fm. - supposed Limestone
Toc Tat Fm. (Devonian)

Silty limestone

Aquitard

Na Quan Fm. (Devonian)

Limestone with shale lenses Fractured aquifer

\section{Mia Le Fm. (Devonian)}

Porous aquifer

Song Cau Fm. (Silurian)

Silt- and claystone

Aquitard
Sand- and siltstone
Fig. 1 a Location of the study site on an excerpt of the World Karst Aquifer Map (Goldscheider et al. 2020). Distribution of carbonate rocks in Vietnam and adjacent countries in blue. b Geological map of the Ma Le Valley, including surface streams and the known cave stream, and sampling sites for measurement campaigns 1 (black symbols) and 2 (colored stars); the topographical catchment delineation for drinking water withdrawal is highlighted. c Cross-section through the Ma Le Valley from northeast to southwest 
1,492 m-long active and partly accessible cave system (Fig. 1). A connection from the swallow hole to the resurgence of the cave stream (cs-out) was confirmed by tracer tests; the mean flow velocity in the cave system varies between $183 \mathrm{~m} / \mathrm{h}$ in the dry season and $1,043 \mathrm{~m} / \mathrm{h}$ in the rainy season (Ender et al. 2018). After its cave passage, water from the Ma Le catchment enters the Seo Ho River. The raw water for the water supply is abstracted from the surface water of the Seo Ho River.

The catchment area of the Ma Le Valley is characterized by two stratigraphic zones (Fig. 1). The northern part consists of the Devonian formations Toc Tat, Na Quan, and Mia Le, composed of unkarstified silty limestone and sandstone, from the shelf facies in the Middle Devonian to the pelagic facies in the Upper Devonian. To the southwest, the 800-m-thick Carboniferous and Permian Bac Son Formation, structured by marine and siliceous limestone, overlies the Devonian formations dipping southwest. This massive unit is intensely karstified. Due to neotectonic activities and resulting karstification, the region is characterized by high relief with deeply incised valleys and large cave systems (Komatsu et al. 2018; Lepvrier et al. 2011; Tam and Batelaan 2011). Several springs draining into the Ma Le River are located at the boundary between karst and nonkarst. There is no surface runoff in the entire karst area. Rainwater percolates through vertical karst fractures, swallow holes, and depressions. The subtropical monsoon climate, with a rainy season from May until October and a dry season from November until April, intensifies karstification processes (Khang 1985).

\section{Sampling campaigns}

The water withdrawn for human use (Fig. 1b) consists of a mix of surface runoff, water from karst springs, and water from nonkarst springs. Some of these springs are more than $7 \mathrm{~km}$ away from the diversion point. Due to this great distance, water quality can be influenced by several factors in this way: agricultural use of the area, transport processes in the surface stream, and the Ma Le cave system. To investigate the spatial changes and the heterogeneity of transport parameters and water quality, two sampling campaigns were carried out. For the first sampling campaign, 49 sampling sites were defined in the entire catchment area (Fig. 1b) and categorized into the following four hydrogeological groups: karst springs, nonkarst springs, surface stream, and cave stream. The sampling sites at the springs record the initial water quality and provide information about the characteristics of their catchment areas. For the sampling sites in the surface stream and the cave system, changes in water quality and their influences were documented. Additionally, the study distinguishes between karst and nonkarst springs. During several field campaigns, the concentration of suspended particles, E. coli, and discharge was measured at all 49 sampling sites twice during both rainy and dry seasons.

The nonkarst springs in the study area are nearsurface springs with a mostly low discharge $(<5 \mathrm{~L} / \mathrm{s})$ draining the silt- and sandstones in the north of the catchment area. The karst springs drain the limestone formation in the southwest of the catchment area, and their discharge fluctuates strongly depending on the season.

Based on the results of the preliminary investigations, a subset of representative locations was selected for more detailed measurement series to further characterize particle concentration, turbidity, and E. coli; each series consists of two paired locations sampled simultaneously for $17 \mathrm{~h}$. These investigations aimed to obtain precise information about fluctuations in water quality, depending on the time of day and changes between the springs/sampling locations and the tapping site. In total, three measurement series were carried out at constant flow conditions (Fig. 1b; Table 1).

The first targets the differences in water quality between the karst springs and nonkarst surface runoff in the catchment area. For this purpose, the water quality at a karst spring and a nearby surface runoff site was monitored. Measurement series 2 focuses on the effects of surface inflow and intensive agriculture on the water quality of the river. For this purpose, water quality was monitored at the swallow hole in the Ma Le Valley (mix-su-2) and 1,800 m upstream (mix-su-1) simultaneously. Measurement series 3 was designed to characterize transport processes and possible underground inflows in the cave system. For this purpose, water quality was monitored at the swallow hole (mix-su-2) and the resurgence of the cave stream (cs-out) simultaneously. The specific sampling intervals for each site (Fig. 1b) are listed in Table 1.

Depending on local conditions, the discharge was measured for both sampling campaigns with a bucket and a stopwatch (low discharge, clear capture of entire flow), or with the salt-dilution method (high discharge, turbulent flow conditions; Groves 2007). For sampling campaign 2, the discharge was measured every $3 \mathrm{~h}$. Since the deviation between individual measurements is less than $5 \%$ and there was no precipitation, constant hydrologic conditions are assumed for all measurement series.

\section{Measurements and analyses}

\section{Suspended particle concentration}

The concentration of suspended particles in a range from 1 to $450 \mu \mathrm{m}$ was measured with portable particle counters (PCSS fluid lite, Klotz GmbH, Bad Liebenzell, Germany). 
Table 1 Principal goals and sampling intervals for sampling campaign 2 (for locations see Fig. 1b) at constant conditions; the data for distance and flow velocity refer to the two sampling sites of the respective measurement series

\begin{tabular}{|c|c|c|c|c|c|c|}
\hline \multirow[t]{2}{*}{ Parameter } & \multicolumn{2}{|c|}{$\begin{array}{l}\text { Measurement series } 1 \text { (nonkarst - } \\
\text { karst) }\end{array}$} & \multicolumn{2}{|c|}{ Measurement series 2 (surface stream) } & \multicolumn{2}{|c|}{ Measurement series 3 (cave system in-out) } \\
\hline & $\begin{array}{l}\text { Nonkarst surface } \\
(n k-s u)\end{array}$ & $\begin{array}{l}\text { Karst spring } \\
(k a-s p)\end{array}$ & $\begin{array}{l}\text { Mix surface stream } 1 \\
(m i x-s u-1)\end{array}$ & $\begin{array}{l}\text { Mix surface stream } 2 \\
(m i x-s u-2)\end{array}$ & $\begin{array}{l}\text { Mix surface stream } 2 \\
(m i x-s u-2)\end{array}$ & $\begin{array}{l}\text { Cave system out } \\
(c s-o u t)\end{array}$ \\
\hline \multicolumn{7}{|c|}{ Principal goals of sampling } \\
\hline All sampling sites & \multicolumn{2}{|c|}{$\begin{array}{l}\text { - Water quality } \\
\text { - Fluctuations during time of day }\end{array}$} & \multicolumn{2}{|c|}{$\begin{array}{l}\text { - Water quality } \\
\text { - Fluctuations during time of day }\end{array}$} & \multicolumn{2}{|c|}{$\begin{array}{l}\text { - Water quality } \\
\text { - Fluctuations during time of day }\end{array}$} \\
\hline $\begin{array}{l}\text { Single } \\
\text { measurement } \\
\text { series }\end{array}$ & \multicolumn{2}{|c|}{$\begin{array}{l}\text { - Differences in water quality } \\
\text { nonkarst-karst } \\
\text { - Influence of catchment area on } \\
\text { water quality }\end{array}$} & \multicolumn{2}{|c|}{$\begin{array}{l}\text { - Overland inflow } \\
\text { - Anthropogenic influence }\end{array}$} & \multicolumn{2}{|c|}{$\begin{array}{l}\text { - Transport processes in cave stream } \\
\text { - Underground inflow }\end{array}$} \\
\hline \multicolumn{7}{|l|}{ General information } \\
\hline Sampling date & 16.11.2017 & 16.11 .2017 & 25.10 .2017 & 25.10 .2017 & 04.11 .2017 & 04.11 .2017 \\
\hline Sampling time & $06: 30-23: 00$ & $06: 30-23: 00$ & $06: 50-23: 00$ & $06: 20-23: 00$ & $06: 00-22: 00$ & $06: 45-23: 00$ \\
\hline Discharge & $48 \mathrm{~L} / \mathrm{s}$ & $78 \mathrm{~L} / \mathrm{s}$ & $547 \mathrm{~L} / \mathrm{s}$ & $754 \mathrm{~L} / \mathrm{s}$ & $462 \mathrm{~L} / \mathrm{s}$ & $640 \mathrm{~L} / \mathrm{s}$ \\
\hline Distance & - & - & $2,150 \mathrm{~m}$ & $2,150 \mathrm{~m}$ & $1,492 \mathrm{~m}$ & $1,492 \mathrm{~m}$ \\
\hline Flow velocity & - & - & - & - & $663 \mathrm{~m} / \mathrm{h}^{\mathrm{a}}$ & $663 \mathrm{~m} / \mathrm{h}^{\mathrm{a}}$ \\
\hline \multicolumn{7}{|l|}{ Sampling interval } \\
\hline $\mathrm{PSD}^{\mathrm{b}}$ & $90 \mathrm{~s}$ & & $90 \mathrm{~s}$ & & $90 \mathrm{~s}$ & \\
\hline Turbidity & $60 \mathrm{~min}$ & & $60 \mathrm{~min}$ & & $60 \mathrm{~min}$ & \\
\hline E. coli & $60 \mathrm{~min}$ & & $60 \mathrm{~min}$ & & $60 \mathrm{~min}$ & \\
\hline
\end{tabular}

${ }^{\text {a }}$ After Ender et al. (2018)

${ }^{\mathrm{b}} P S D$ particle-size distribution

To avoid sedimentation and aggregation, particle concentrations were measured in situ. At each sampling site, the differences in variations between 1 and $10 \mu \mathrm{m}$ are small, and the number of particles larger than $15 \mu \mathrm{m}$ is negligibly low. For reasons of clarity, this study focuses only on three classes: $1-2 ; 4-5$; and $10-15 \mu \mathrm{m}$. The size of coliform bacteria is between 1 and $3 \mu \mathrm{m}$ (Reshes et al. 2008); Pronk et al. (2007) found a strong correlation between fine particles and fecal contamination; therefore, the smallest fraction was compared with E. coli.

For the initial sampling campaign at 49 sites, ten 10$\mathrm{ml}$ measurements for each sample were taken to ensure reproducibility and calculated the arithmetic mean. Before each series of measurements, the instrument was flushed with $30 \mathrm{ml}$ of ultrapure water and $50 \mathrm{ml}$ of sample water. For the second, high temporal resolution sampling campaign, a rinsing cycle and a subsequent measurement every $90 \mathrm{~s}$ were performed.

\section{Fecal indicator bacteria (FIB)}

For FIB analysis, water samples were taken in 100-ml sterile, plastic bottles containing $250-\mu 1$ sodium thiosulfate. The samples were stored in the dark at $4{ }^{\circ} \mathrm{C}$ and analyzed within $12 \mathrm{~h}$. The analysis was performed according to the IDEXX colisure procedure (IDEXX Laboratories Inc., Westbrook, USA). Based on the Quanti-Tray/2000 method, bacteria are identified as the most probable number (MPN) of colony-forming units in $100 \mathrm{ml}$. This analysis is approved by US EPA, included in the Standard Methods for Examination of Water and Wastewater, and recommended for remote applications (Abramson et al. 2013).

\section{Statistical analysis}

To quantify relationships between data populations from the rainy and dry seasons, the Wilcoxon rank-sum test was performed. A seasonal difference is considered significant at the $99 \%$ confidence level. Statistical analysis of differences between different types of sampling locations in the wet season and dry season for the parameters of particle concentration and E. coli were performed with a one-way variance analysis (ANOVA). The homogeneity of the variances was calculated for all measurement series in sampling campaign 2 with Levene's test by testing the null hypothesis against the alternative hypothesis. Spearman's rank correlation was applied to 
examine the relationship between two variables (analyzed parameters: particle, turbidity, E. coli) without assuming a probability distribution. Statistical data analyses were conducted using the software package OriginPro 9.6 (Levene's test, ANOVA) and PAST 3.25 (Wilcoxon rank-sum test, Spearman's rank correlation).

\section{Results and discussion}

\section{Sampling campaign 1}

Figure 2 summarizes the results of sampling campaign 1 graphically, and statistically evaluates the seasonal variations by using the Wilcoxon rank-sum test. Table 2 shows the significant difference between the individual sampling site categories for rainy and dry seasons.

In the rainy season, the range of all measured values for particle concentrations is largest for karst springs (1-2 $\mu \mathrm{m}: 6,000-595,000 \mathrm{n} / 10 \mathrm{ml})$ and smallest for samples in the cave system (1-2 $\mu \mathrm{m}$ : 360,000-611,000 $\mathrm{n} / 10 \mathrm{ml}$ ). Particle concentrations of all size classes were significantly higher in the rainy season than in the dry season, except for karst springs (10-15 $\mu \mathrm{m}$; Fig. 2). The larger the diameter of the suspended particles, the lower their concentration. Particle concentrations increase for all size classes from springs (karst and nonkarst) to the surface runoff and cave system. In the rainy season, these differences are significant (Table 2); furthermore, the microbial pollution at springs in the project area is lower than at sampling sites in surface streams and cave systems (Fig. 2). Nevertheless, the number of bacteria always exceeds the maximum value recommended by the WHO (2011) for drinking water $(<1 \mathrm{MPN} / 100 \mathrm{ml})$ at all monitoring sites. In contrast to other studies (e.g. Kapembo et al. 2016), a significantly higher concentration of $E$. coli at karst springs during the rainy season was not observed (Fig. 2).

Seasonal differences in water quality are caused by more and stronger precipitation events in the rainy season, leading to more surface runoff that flushes particles from the surface into the stream and swallow holes (Pronk et al. 2009). During the rainy season, discharge is higher than in the dry season (e.g. cs-out: 809-163 L/s). As previous studies on particle-size investigations at karst springs showed, higher discharge leads to more turbulent flow and thus more suspended particles (Schiperski et al. 2015; Atteia and Kozel 1997). Despite higher discharge during the rainy season, the particle concentration is lower at karst springs than at nonkarst springs and surface stream sampling sites with comparable or even lower discharge conditions (Fig. 3). Because of their high permeability, karst aquifers are particularly vulnerable to contamination (Ivan and Madl-Szonyi 2017; Nguyet and Goldscheider 2006b); however, the karst springs in the study area show lower pollution levels in comparison to the heavily polluted surface stream. Large quantities of pollutants are flushed into the Ma Le River by unfiltered sewage disposal and thus worsen the water quality of the surface stream. This disposal has no seasonal fluctuations. These findings suggest that, in this study area, anthropogenic land-use activities in the individual catchment areas, such as farming and settlements, have a higher influence on water pollution than the hydrologic and
Table 2 Statistical analysis of the difference between different types of sampling locations in the wet season (top right part of the table) and dry season (bottom left part of the table) of the particle concentrations: 1-2 $\mu \mathrm{m}$ (first data value), 4-5 $\mu \mathrm{m}$ (second data value), $10-15 \mu \mathrm{m}$ (third data value), and E. coli (last data value) with one-way variance analysis. Significant differences $(p<0.05)$ are in italics

\begin{tabular}{lllll}
\hline & Karst springs & Nonkarst springs & Surface stream & Cave system \\
\hline Karst springs & - & 0.382 & $<0.001$ & $<0.001$ \\
& & 0.733 & 0.004 & $<0.001$ \\
Nonkarst springs & 0.153 & 0.019 & $<0.001$ \\
& 0.440 & 0.243 & 0.243 & 0.442 \\
& 0.133 & - & $<0.001$ & $<0.001$ \\
Surface stream & 0.045 & & 0.002 & $<0.001$ \\
& 0.929 & & 0.301 & $<.001$ \\
& 0.005 & $<0.001$ & 0.697 & $<0.001$ \\
Cave system & 0.676 & 0.159 & - & $<0.001$ \\
& 0.041 & 0.612 & & 0.004 \\
& 0.057 & 0.087 & & - \\
& $<0.001$ & $<0.001$ & 0.008 & \\
& 0.112 & 0.004 & 0.026 & \\
\hline
\end{tabular}




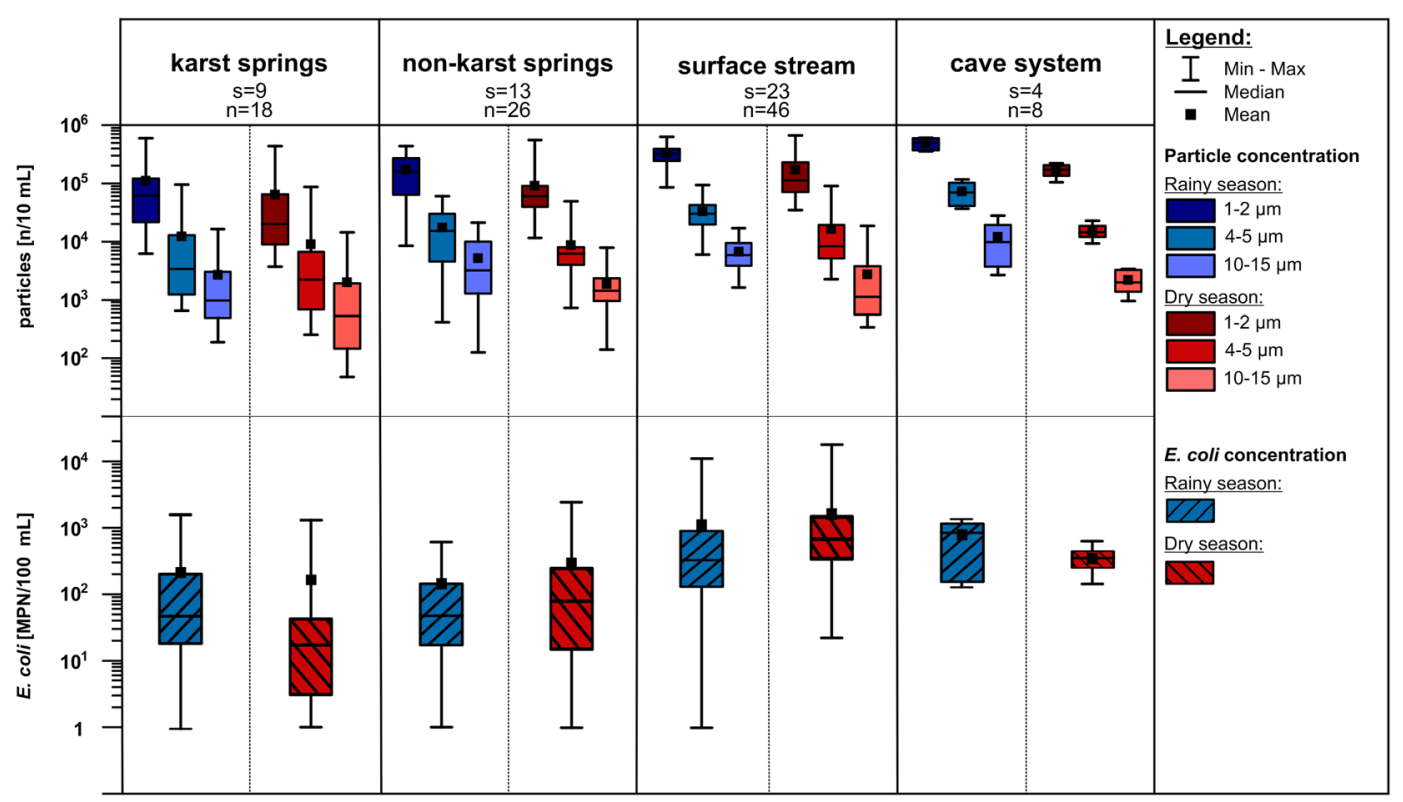

\begin{tabular}{|c|c|c|c|c|}
\hline & \multicolumn{4}{|c|}{$\underset{\text { rainy season - } d r y \text { season }}{\text { Wilcoxon rank-sum test }}$} \\
\hline & $\begin{array}{c}\text { karst springs } \\
\mathrm{s}=9\end{array}$ & $\begin{array}{c}\text { non-karst springs } \\
\mathrm{s}=13\end{array}$ & $\begin{array}{c}\text { surface stream } \\
\qquad s=23\end{array}$ & $\begin{array}{c}\text { cave system } \\
\mathrm{s}=4\end{array}$ \\
\hline $1-2 \mu \mathrm{m}$ & 0.021 & $<0.001$ & $<0.001$ & $-*$ \\
\hline $4-5 \mu \mathrm{m}$ & 0.035 & 0.001 & $<0.001$ & $-^{*}$ \\
\hline $10-15 \mu \mathrm{m}$ & 0.099 & 0.002 & $<0.001$ & $-^{*}$ \\
\hline E. coli & 0.138 & 0.310 & 0.023 & $-^{*}$ \\
\hline
\end{tabular}

Fig. 2 Concentrations of suspended particles, and E. coli for the karst springs, the nonkarst springs, the surface stream locations, and the cave system locations. For the concentrations of suspended particles, the three size classes $1-2,4-5$, and $10-15 \mu \mathrm{m}$ in the rainy (blue) and dry (red) seasons are shown. $s=$ number of sampling locations; $n=$ number of samples per season. The Wilcoxon rank-sum test reveals the statistical differences between rainy and dry seasons, significant differences $(p<0.05)$ are in italics. ${ }^{*}$ data quantity for statistical evaluation not sufficient hydrogeological conditions and must be particularly considered for the development of a water protection concept.

\section{Sampling campaign 2: high-resolution measurement series}

The degradation of water quality from the springs to the diversion site guided the selection of sampling sites for campaign 2. The sites were chosen for detailed investigations of different hydrological components (karst and nonkarst springs, Ma Le Valley, cave system) and their influences in the catchment area. The results of the three measurement series are summarized in Fig. 4; time series and statistical analyses are given in the electronic supplementary material (ESM).

Over half of the total discharge originates from several small karst springs in the Ma Le Valley (Fig. 3). To assess their water quality, measurement series 1 compares the water quality at a karst spring (ka-sp; blue) and a nearby surface stream (nk-su; red). The karst spring and the surface stream show significant differences in water quality for particle concentrations and FIB (Table S1 in the ESM). At the karst spring, particle concentrations, turbidity and E. coli were constant over the entire $17-\mathrm{h}$ period of the measurement series. Measured particle and bacterial concentrations at ka-sp were the lowest in the entire study area (Table S1 in the ESM). At site nk-su, several peaks were detected for all parameters. $E$. coli concentration indicates very high microbial contamination (Table S1 in the ESM, mean 6,332 MPN/100 ml). In the surface stream, fluctuations in particle concentration always happen within a few minutes without distinct tailing; therefore, the sampling site must be located close to the origin of contamination disposal.

Series 2 focused on the water quality of the Ma Le River to assess anthropogenic impacts in the intensively cultivated $\mathrm{Ma}$ Le Valley. For this purpose, time series in the Ma Le River were recorded simultaneously at two sampling sites: mix-su-1 and mix-su-2 (1,800 $\mathrm{m}$ downstream). The concentration of suspended particles shows short-term variability between 7:30 and 17:30 at both sampling sites; after 21:00, particle 


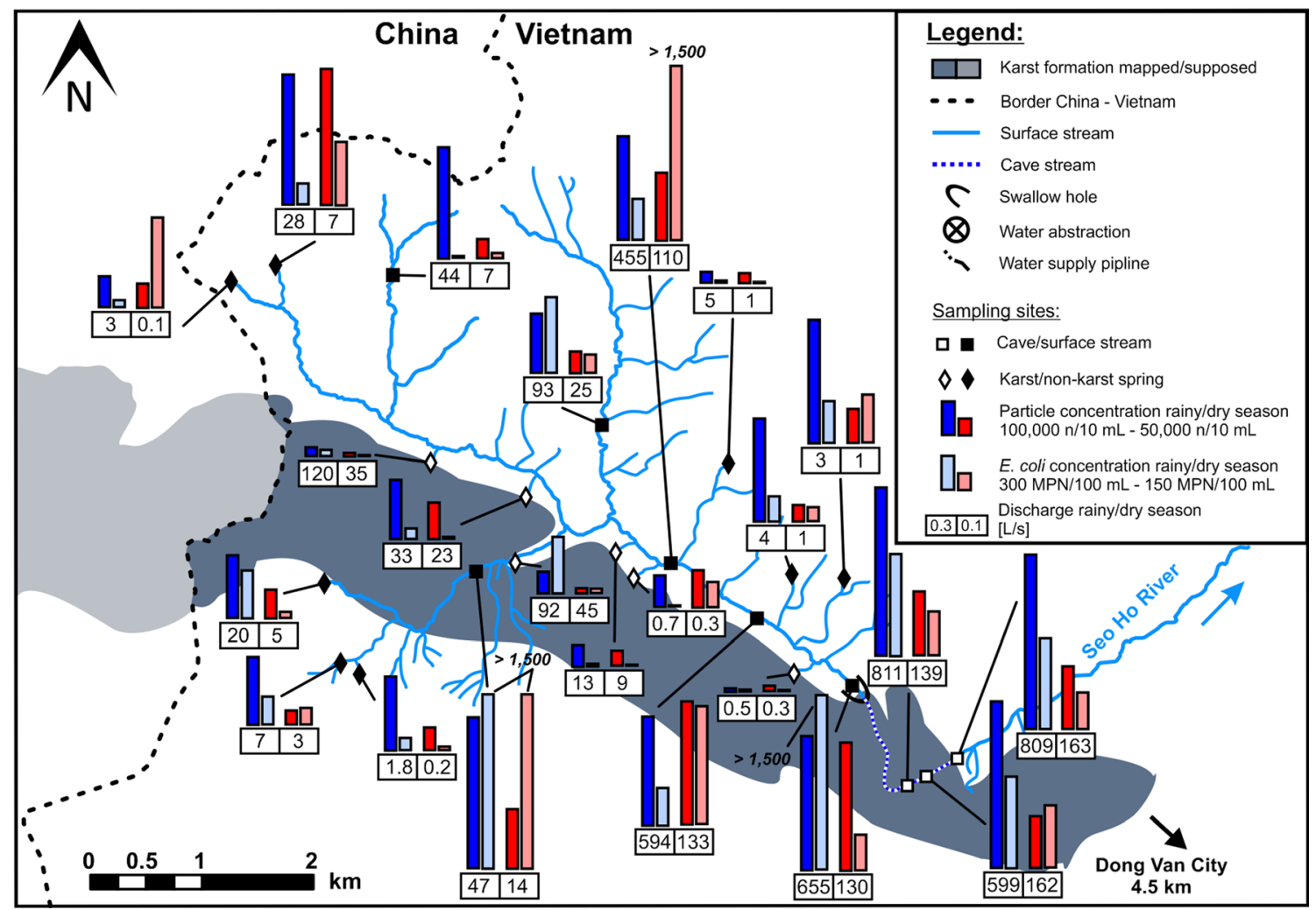

Fig. 3 Mean particle concentrations (1-2 $\mu \mathrm{m})$, E. coli concentrations, and discharge for selected sampling sites during the rainy (blue) and dry (red) seasons

concentrations return to the initial level recorded at the beginning of the measurement period. Particle concentrations increase significantly between the two sampling sites with $p<0.001$ (Table S1 in the ESM). E. coli concentrations indicate strong microbial contamination at both sites (Table $\mathrm{S} 1$ in the ESM: mix-su-1, mean $866 \mathrm{MPN} / 100 \mathrm{ml}$; mix-su-2, mean $691 \mathrm{MPN} / 100 \mathrm{ml}$ ).

Following the catchment area of the springs (measurement series 1) and surface runoff (series 2), the cave system is the third important hydrologic compartment influencing water quality in the study site. To understand the cave system's impacts, the water quality at the sink of the Ma Le River (mix-su-2) was monitored, along with the resurgence of the cave stream (cs-out) over $17 \mathrm{~h}$ (series 3). Large fluctuations in the concentration of suspended particles were measured depending on the time of day. At sampling site mix-su-2, single events cause rapid increases of particle concentrations in the afternoon. At cs-out, the lowest particle concentrations were measured in the afternoon and at night. Fluctuations in particle concentrations at mix-su- 2 occur over a few minutes, whereas fluctuations at cs-out are more attenuated. Considered over the entire measurement period, particle concentrations on average are significantly higher at the resurgence than at the swallow hole (Fig. 4; Table S1 in the ESM). The microbial contamination is high at both sampling sites (Table S1 in the ESM: mixsu-2, mean $711 \mathrm{MPN} / 100 \mathrm{ml}$; cs-out, mean $439 \mathrm{MPN} /$
$100 \mathrm{ml}$ ), no significant differences were found. Several concentration peaks (E. coli, and particles) were measured at the swallow hole, which was no longer or only in a reduced form detectable at the resurgence of the cave stream.

The results reveal the lowest microbial pollution at the small karst springs in the upper section of the valley and a significant deterioration of the water quality in further surface runoff. The cave system also influences the water quality; furthermore, the data demonstrate that constant hydraulic conditions do not always accompany constant water quality, as already mentioned by Frank et al. (2018). The influence of an intensively cultivated, rural area can significantly increase the number of pollutants in the water within a few minutes.

Constant and moderate concentrations of all measured parameters at ka-sp indicate that its recharge area is more pristine and mountainous, as human settlements over a karst aquifer increase the number of particles (Mahler et al. 1999). Nevertheless, percolation following rainfall on karst could increase direct particle transfer from the soil, often accompanied by high levels of fecal bacteria (Pronk et al. 2009).

Single peaks of particle concentrations in the surface stream can be assigned to single mobilization events, flattened peaks after sunset originate from events further upstream. As more and higher particle peaks are detected at the downstream sampling site mix-su-2, several contamination hotspots are located in the Ma Le Valley, close to 


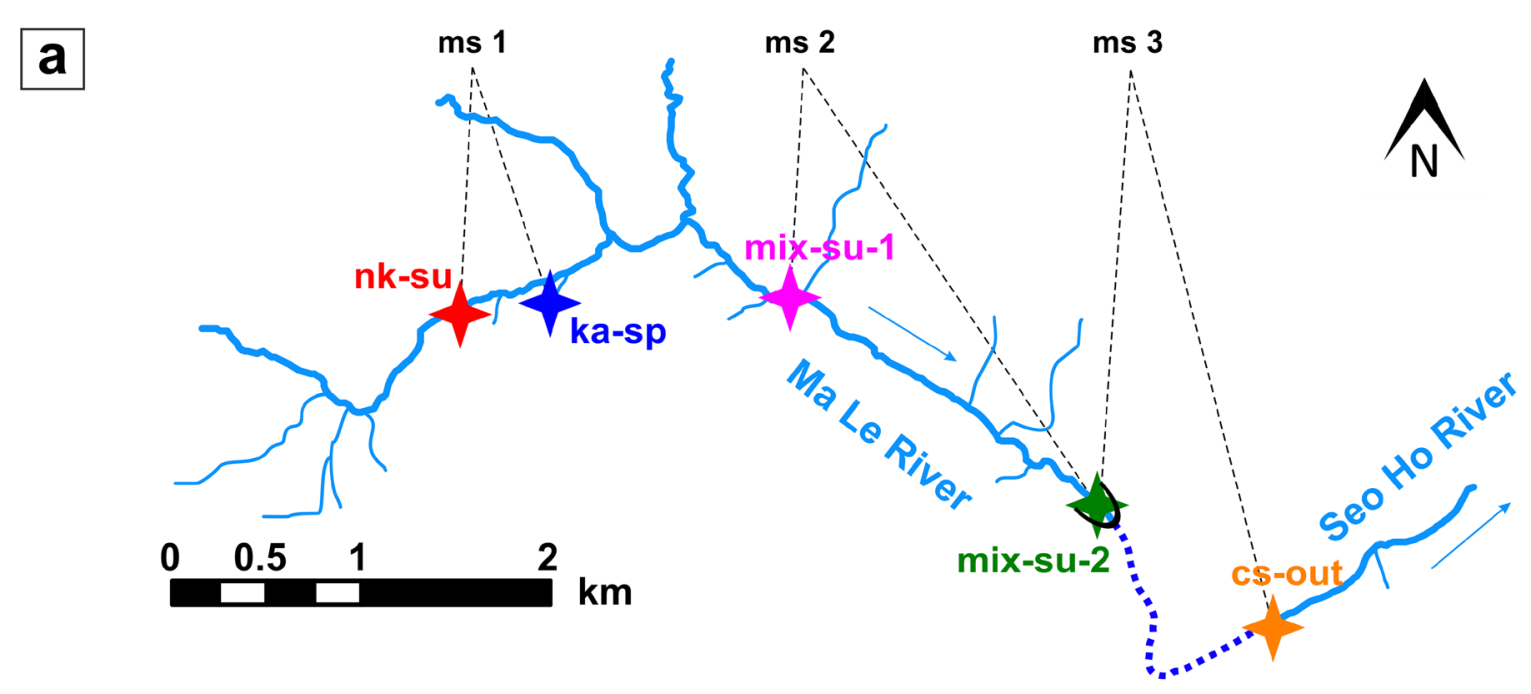

b

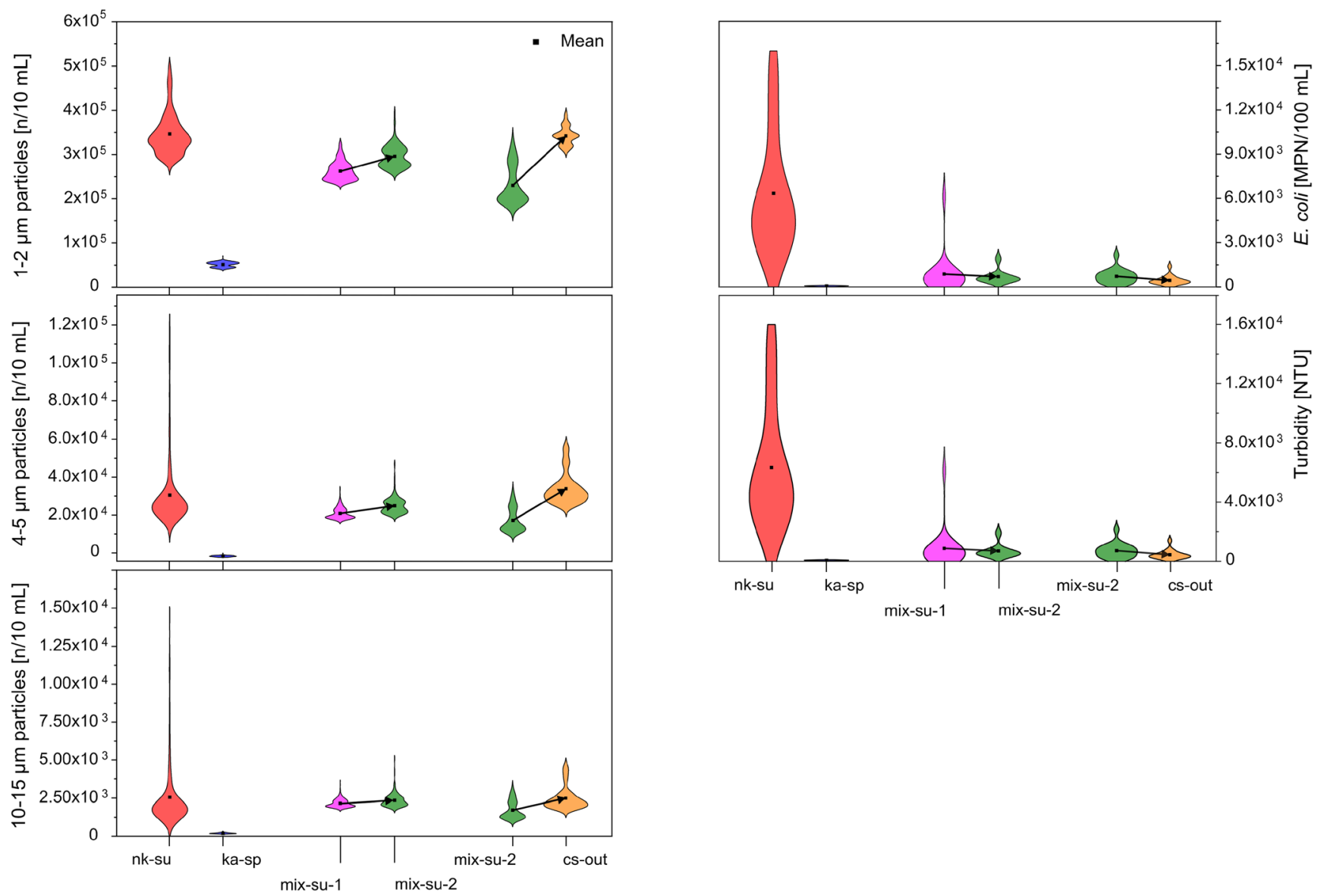

Fig. 4 a Location of sampling sites in the stylized Ma Le River. b Distribution of particles $(1-2,4-5,10-15 \mu \mathrm{m})$, E. coli, and turbidity for measurement series 1 (ms 1), 2, and 3. Black arrows indicate a downstream location of the second sampling site

the stream. In addition to the spatial variations in water quality, temporal differences can also be found. Higher particle concentrations in the daytime are associated with anthropogenic activities like farming (fishing, plowing, grazing cows) and sewage disposal (Figs. S1 and S2 in the ESM). 
The results of measurement series 3 emphasize, that the Ma Le cave system is a highly dynamic system with additional inflows and partly active bypass flowpaths. Similar to previous studies of particle concentrations in karst systems, the damping of the larger particles in the cave system is most likely achieved by kinetic processes such as sedimentation or attachment to an immobile phase and surface (Schiperski et al. 2016; Cholet et al. 2017). However, autochthonous remobilization of intrakarstic sediments by erosion in the cave system may lead to partly higher particle concentrations at the resurgence. Since measurement series 3 was performed under constant hydrologic conditions, particle peaks detected at the cave stream resurgence, but not at the swallow hole, and a higher discharge at cs-out, indicate underground inflows to the system. Particularly for larger particles $(>10 \mu \mathrm{m})$, sedimentation effects were ascertained in the cave stream. Consequently, the Ma Le cave system can act as a buffer for particle peaks from the Ma Le Valley during constant hydrologic conditions. However, potential effects of remobilization and subsurface inflows can also increase the background particle concentrations; therefore, daytime activity-induced fluctuations from the Ma Le Valley can only be detected to a limited extent at the resurgence of the cave stream.

\section{Correlation analysis}

Spearman's rank correlation was applied to determine the correlation coefficient rs for all six sampled sites (see Tables S2-S4 in the ESM). At every site, individual particle classes show a strong correlation with each other. Turbidity correlates significantly with all three particle classes at four sites; the smaller the particle diameter the stronger the correlation.

Several studies show significant correlations between suspended particles and microbial contamination, especially $E$. coli. The process of mobilization is often similar, and bacteria attached to particles are more persistent (e.g. Pronk et al. 2007; Mahler et al. 2000; Abberton et al. 2016). Abia et al. (2016) posited that riverbed disturbances increase the risk of infection due to E. coli 10 -fold; however, the data of the study area indicate an increase in particle concentration, which does not always come along with degradation of microbial water quality. Due to intensive land use in the catchment, mobilization of sediments from the river bed (e.g. roads are crossing the river without bridges) can lead to a short-term, large increase in suspended particles without a significant change in the number of FIB. Similarly, direct dumping of wastewater can cause a large degradation in water quality without directly affecting turbidity or counts of suspended particles in river water. In this respect, monitoring indicator parameters such as turbidity alone is not sufficient for a comprehensive assessment of water quality in the study site.

\section{GIS analyses of land use}

To evaluate the data in the context of land use and to identify areas facilitating the mobilization of contaminates, GIS analyses were conducted. The results are presented in a map of the catchment area (Fig. 5). For this purpose, land use was grouped into four categories based on contaminant potential: settlements, agriculture, forest, and bare rock. Settlements include rural residential and commercial buildings, public infrastructure, and military areas; agriculture includes pastureland and cultivated areas.

Large areas of the catchment are forested or fallow. The steep slopes of the valley are mostly used for growing corn; close to springs and little creeks, rice terraces are stepped into the hillsides, through which water is drained in daily changed patterns of channel systems. The flat valley plains serve as grazing land for cows and goats, often on fallows. Local people live in far-flung settlements in the mountainous area; the majority sustaining themselves on agriculture. The biggest potential sources of contamination are concentrated in the basin of Ma Le valley and around settlements.

To highlight the impact of land use on the water quality of the Ma Le River, Fig. 6 illustrates the microbial pollution in combination with the distribution of land use in the catchment area for each sampling site. For the sites in the surface stream and cave stream, the catchment areas were calculated with the watershed tool of the software package ArcSWAT for ArcGIS 10.7 from a hybrid digital elevation model and the river network (Zindler B, Stolpe H, Greassidis S, Ruhr University Bochum, Institute of Environmental Engineering and Ecology, Joint R\&D project KaWaTech Solutions: Technical solutions for karst water supply, subproject 4, water protection measures, unpublished report, 2020). The catchment delineation of the individual springs was estimated based on the mean annual discharge, the local hydrostratigraphy and geological structure, and the groundwater recharge ( $\mathrm{Vu}$ and Merkel 2019; Lacombe et al. 2017). Due to limited accessibility, for transboundary catchments, only the land use in the Vietnamese part is to be considered.

Despite partly small distances of karst springs to agricultural areas and settlements, these springs are mostly only slightly microbial contaminated (Fig. 6). Consequently, these areas only have a small influence on the water quality of karst springs in the project area; groundwater recharge occurs mainly from areas with bare rocks. Only one karst spring shows very high $E$. coli concentrations, originating from discharged wastewater from the populated area in the south of the study site.

Nonkarst springs with largely forested catchments and bare rocks have a similar low microbial contamination as karst springs; however, the results also show that area-wise increasing agriculture and settlement in the catchments of nonkarst springs are leading to a degradation of water quality (Fig. 6). Three nonkarst springs show very low concentrations of 


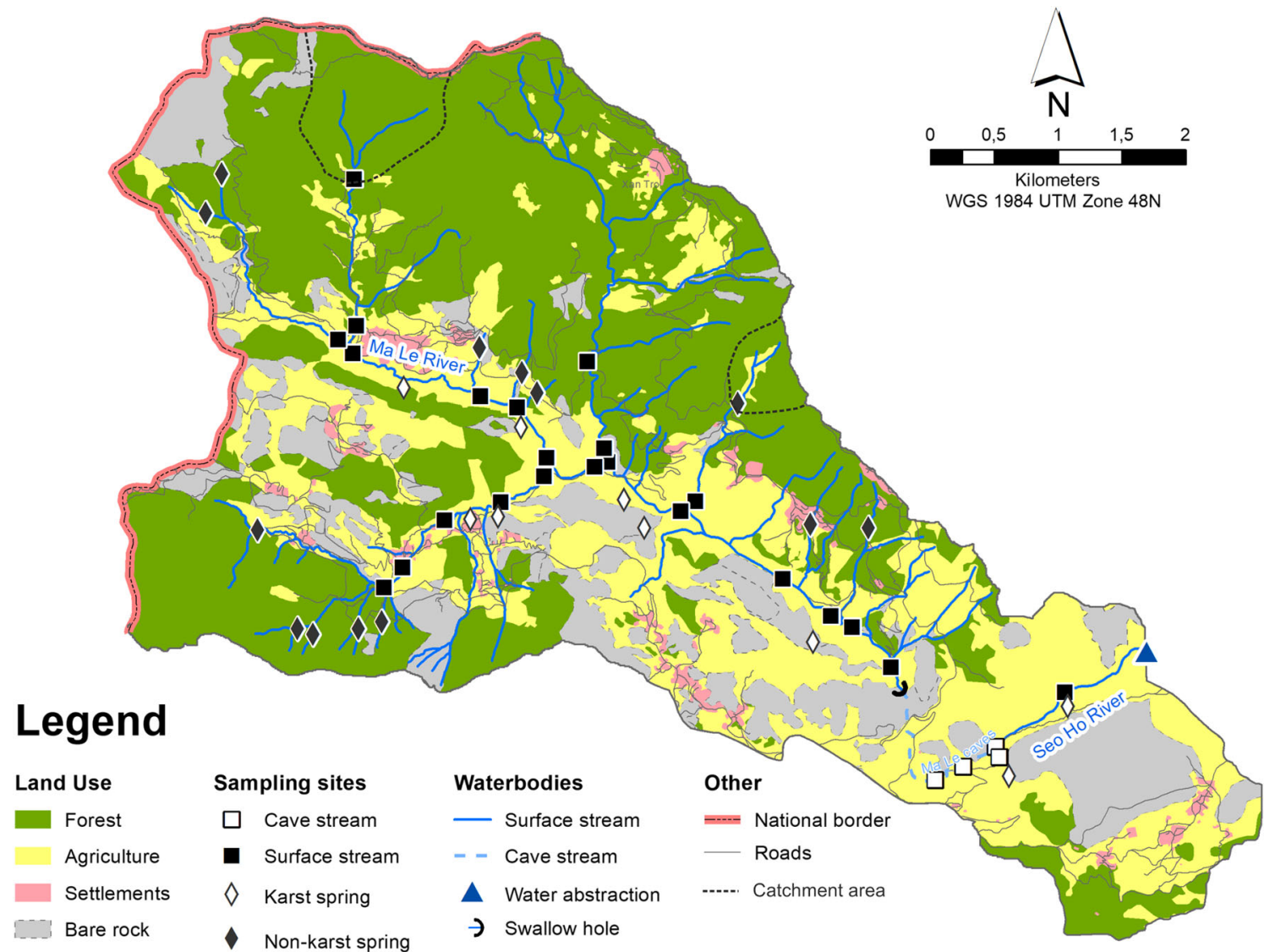

Fig. 5 Map of the land use in the catchment, including all 49 sampling sites of sampling campaign 1. The land-use category "settlements" includes residential areas, public infrastructure, and military areas; the category "agriculture" includes pastureland, and cultivated areas. The estimated catchment areas of one spring and one sampling site in the surface

stream are shown exemplarily. The data for streets are based on Open Street Map (2019), rivers are from MoNRE (modified, unpublished data, 2019), and land use from DoNRE Ma Le and DoNRE Ta Lung (modified, unpublished data, 2018)
Fig. 6 Grouping of water-quality sampling sites into karst springs, nonkarst springs, and sampling sites in the surface stream and the cave stream. The sampling sites in each group are ranked by increasing percentage of settlements and agriculture in their respective catchments. The land use is divided into four categories; red: settlements, yellow: agriculture; green: forest; grey: bare rock. Mean E. coli concentration of each sampling site is illustrated by black dots. The black line indicates the trend of increasing E. coli concentration by accretive agriculture and settlements in the catchment areas

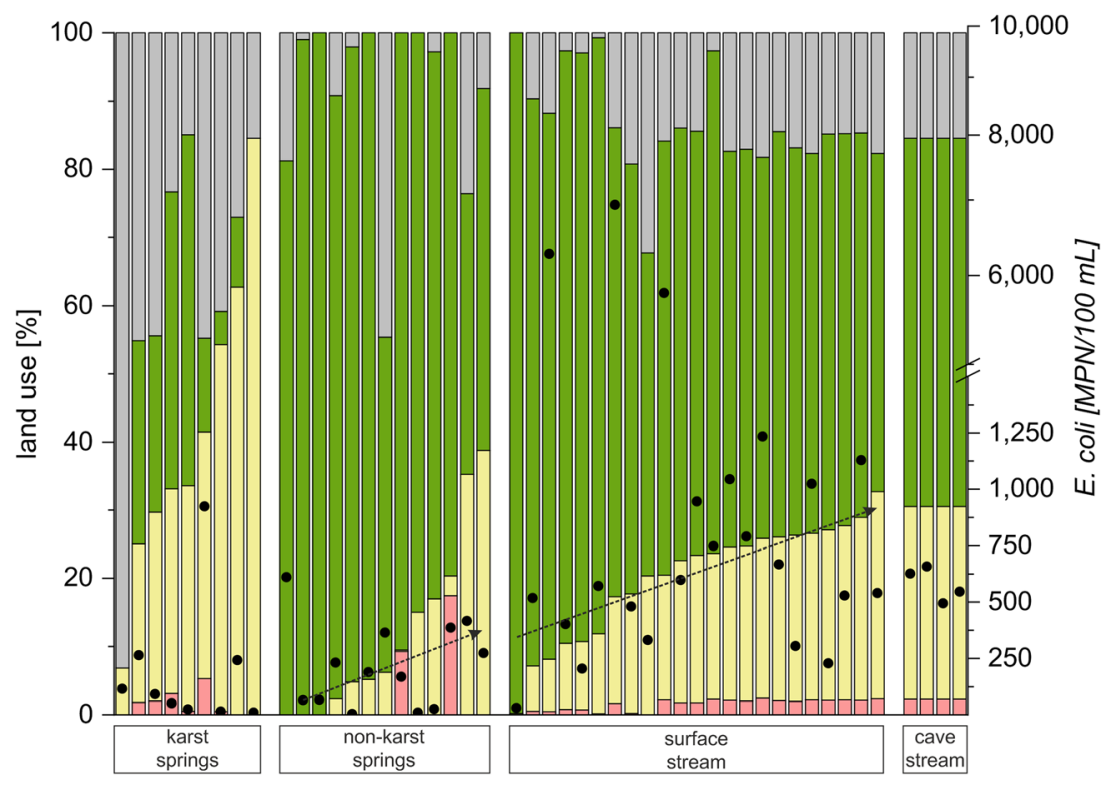


E. coli, despite agricultural land in their catchments. These springs are used by the local population for drinking water.

The sampled sites in the Ma Le River also show the trend of higher contamination with more agricultural land in their catchments. Due to the proximity of farmland and settlements to surface streams in the study site, microbial contamination is highest here. In particular, very high concentrations of $E$. coli were measured at three sampling sites, located near settlements; the high levels of FIB indicate unfiltered sewage disposal immediately upstream.

Despite contrasting juxtaposition of karst and nonkarst terrain on either side of the basin, the water quality in Ma Le Valley is mainly influenced by residential areas and farmland. The distinct surface runoff and high flow velocities in the mountainous study site cause a high risk of contamination for the surface stream. Low contamination risks are only present in areas where natural vegetation covers the aquifers or bare rocks lead to the direct percolation of rainwater.

\section{Conclusions}

This study presents the basis for an adapted protection approach for a complex surface water and karst groundwater system for the Ma Le Valley, northern Vietnam. The characteristic contamination risks for the surface stream and the groundwater in the catchment were addressed by monitoring the spatial and temporal dynamics of suspended particles and E. coli. Additionally, a GIS-based assessment of the impacts of different land uses on the water quality in the catchment is presented and linked to the results of water-quality monitoring.

This study revealed significant seasonal differences in water quality at springs and in the surface stream, and fecal impacts at all sampled sites. In cultivated and agriculturally used regions, short-term and unpredictable deterioration of water quality in the surface stream is possible at any time, especially during the day. Constant discharge does not automatically imply constant water quality; even under stable conditions, a high variability of water quality can occur. The monitoring efforts were able to identify the sources of contamination and the likelihood of contamination in different parts of the catchments. Land-use activities in the study area generally have a higher influence on water quality than hydrologic conditions.

Suspended particle concentrations are a good low-cost proxy for bacterial contamination in catchments with high temporal and spatial variability of water quality. However, in the study site, particle concentrations are insufficient to capture all bacterial concentration spikes. Due to the different mobilization of particles and bacteria, only monitoring turbidity is not sufficient as an early-warning system for microbial pollution. Furthermore, the results of this study demonstrate clear differences in water quality depending on the time of day; at night the water is less polluted.

Based on the combination of GIS analyses of land use and the FIB data, several measures are recommended to reduce pollutant input:

- Treatment of the accruing sewage or equipping buildings with septic tanks

- Prohibition of burning garbage and littering

- Restricted use of agrochemicals, especially in the rainy season

- Reduced farming activities (particularly livestock breeding) in the valley basin

- Shift the timing of drinking water withdrawals to the nighttime

Besides, socio-cultural aspects such as education and awareness of the local population are essential for the downstream users of the river water. To respond to increasing water demand, the existing water supply system could be further enhanced by diverting water from springs with low microbial contamination and adapted protection strategies for their catchments.

This study highlights the seasonal variability of water quality and the large fluctuations in quality, even under constant discharge conditions, in a complex surface water and karst groundwater system. These fluctuations indicate the utility of advanced measurement techniques such as high-resolution particle measurements, to detect and predict the variability of contamination, and provides the basis for innovative and locally adapted water protection strategies. The outlined methodology is also transferable to other complex surface water and karst groundwater sites in subtropical environments.

Supplementary Information The online version contains supplementary material available at https://doi.org/10.1007/s10040-021-02356-6.

Acknowledgements The authors thank the whole sampling team, especially Patrick Keinarth, Nina Schwark, Joel Pompei, Oliver Dott, Niclas Danielzik, Ho Tien Chung, Doan The Anh, Tran Diep Anh, and Nguyen Van Dong for their help during fieldwork. We are grateful to Markus Klotz for the good cooperation and thank him for providing particle counters. Special thanks are given to Chloé Fandel for language checking the manuscript and for her valuable feedback.

Funding Open Access funding enabled and organized by Projekt DEAL. This project was funded by the German Federal Ministry of Education and Research (BMBF) (grant number 02WCL1415).

Open Access This article is licensed under a Creative Commons Attribution 4.0 International License, which permits use, sharing, adaptation, distribution and reproduction in any medium or format, as long as you give appropriate credit to the original author(s) and the source, provide a link to the Creative Commons licence, and indicate if changes were made. The images or other third party material in this article are included in the article's Creative Commons licence, unless indicated otherwise in a credit line to the material. If material is not included in the article's 
Creative Commons licence and your intended use is not permitted by statutory regulation or exceeds the permitted use, you will need to obtain permission directly from the copyright holder. To view a copy of this licence, visit http://creativecommons.org/licenses/by/4.0/.

\section{References}

Abberton CL, Bereschenko L, van der Wielen PWJJ, Smith CJ (2016) Survival, biofilm formation, and growth potential of environmental and enteric Escherichia coli strains in drinking water microcosms. Appl Environ Microbiol 82:5320-5331. https://doi.org/10.1128/ AEM.01569-16

Abia ALK, Ubomba-Jaswa E, Genthe B, Momba MNB (2016) Quantitative microbial risk assessment (QMRA) shows increased public health risk associated with exposure to river water under conditions of riverbed sediment resuspension. Sci Total Environ 566-567:1143-1151. https://doi.org/10.1016/j.scitotenv.2016.05. 155

Abramson A, Benami M, Weisbrod N (2013) Adapting enzyme-based microbial water quality analysis to remote areas in low-income countries. Environ Sci Technol 47:10494-10501. https://doi.org/ 10.1021/es402175n

Atteia O, Kozel R (1997) Particle size distributions in water from karstic aquifer: from particles to colloids. J Hydrol 201:102-119

Cabral JP, Marques C (2006) Faecal coliform bacteria in Febros River (northwest Portugal): temporal variation, correlation with water parameters, and species identification. Environ Monitor Assess 118: 21-36. https://doi.org/10.1007/s10661-006-0771-8

Cholet C, Charlier J-B, Moussa R, Steinmann M, Denimal S (2017) Assessing lateral flows and solute transport during floods in a conduit-flow-dominated karst system using the inverse problem for the advection-diffusion equation. Hydrol Earth Syst Sci 21: 3635-3653. https://doi.org/10.5194/hess-21-3635-2017

Doyle MP, Erickson MC (2006) Closing the door on the fecal coliform assay. Microbe 1(4):162-163

Dussart-Baptista L, Massei N, Dupont JP, Jouenne T (2003) Transfer of bacteria-contaminated particles in a karst aquifer: evolution of contaminated materials from a sinkhole to a spring. J Hydrol 284(1): 285-295

Ender A (2018) Evaluation of highly variable water quality as basis for a sustainable water supply in the Dong Van karst region, Vietnam. $\mathrm{PhD}$ Thesis, Karlsruhe Institute of Technology, Germany. https:// doi.org/10.5445/IR/1000083139

Ender A, Goeppert N, Goldscheider N (2018) Spatial resolution of transport parameters in a subtropical karst conduit system during dry and wet seasons. Hydrogeol J 26:2241-2255. https://doi.org/10.1007/ s10040-018-1746-x

Ford D, Williams P (2013) Karst hydrogeology and geomorphology. Wiley, Chichester, UK

Fournier M, Massei N, Mahler BJ, Bakalowicz M, Dupont JP (2008) Application of multivariante analysis to suspended matter particle size distribution in a karst aquifer. Hydrol Process 22:2337-2345. https://doi.org/10.1002/hyp.6828

Frank S, Goeppert N, Goldscheider N (2018) Fluorescence-based multiparameter approach to characterize dynamics of organic carbon, faecal bacteria and particles at alpine karst springs. Sci Total Environ 615:1446-1459. https://doi.org/10.1016/j.scitotenv.2017. 09.095

Goeppert N, Goldscheider N (2019) Improved understanding of particle transport in karst groundwater using natural sediments as tracers. Water Res 166(2019):115045. https://doi.org/10.1016/j.watres. 2019.115045
Goldscheider N, Pronk M, Zopfi J (2010) New insights into the transport of sediments and microorganisms in karst groundwater by monitoring of particle-size distribution. Geol Croatica 63(2):137-142

Goldscheider N, Chen Z, Auler AS, Bakalowicz M, Broda S, Drew D, Hartmann J, Jiang G, Moosdorf N, Stevanovic Z, Veni G (2020) Global distribution of carbonate rocks and karst water resources. Hydrogeol J. https://doi.org/10.1007/s10040-020-02139-5

Grimmeisen F, Zemann M, Goeppert N, Goldscheider N (2016) Weekly variations of discharge and groundwater quality caused by intermittent water supply in an urbanized karst catchment. J Hydrol 537: 157-170. https://doi.org/10.1016/j.jhydrol.2016.03.045

Groves C (2007) In: Nico G, David D (eds) Methods in karst hydrogeology. Taylor and Francis, London

Ivan V, Madl-Szonyi J (2017) State of the art of karst vulnerability assessment: overview, evaluation and outlook. Environ Earth Sci 76: 112. https://doi.org/10.1007/s12665-017-6422-2

Jiang G, Guo F, Polk JS, Kang Z, Wu J (2015) Delineating vulnerability of karst aquifers using hydrochemical tracers in Southwestern China. Environ Earth Sci 74(2):1015-1027

Kapembo ML, Laffite A, Bokolo MK, Mbanga AL, Maya-Vangua MM, Otamonga J-P, Mulaji CK, Mpiana PT, Wildi W, Pote J (2016) Evaluation of water quality from suburban shallow wells under tropical conditions according to the seasonal variation, Bumbu, Kinshasa, Democratic Republic of the Congo. Exposure Health 8: 487-496. https://doi.org/10.1007/s12403-016-0213-y

Khang P (1985) The development of karst landscapes in Vietnam. Geol Pol 35:305-324

Komatsu T, Urakawa R, Inada T, Yamauchi K, Maekawa T, Takashima R, Williams M, Nguyen PD, Doan H, Nguyen MT, Niko S, Tanaka G, Yamaguchi T (2018) The Kellwasser events in the upper Devonian Frasnian to Famennian transition in the Toc Tat Formation, ietnam. Island Arc 28(1):e12281. https://doi.org/10. 1111/iar.12281

Lacombe G, Douangsavanh S, Vongphachanh S, Pavelic P (2017) Regional assessment of groundwater recharge in the lower Mekong Basin. Hydrology 4:4. https://doi.org/10.3390/ hydrology 4040060

Lepvrier C, Faure M, Van VN, Van Vu T, Lin W, Trong TT, Hoa PT (2011) North-directed Triassic nappes in northeastern Vietnam (east Bac Son). J Asian Earth Sci 41:56-68. https://doi.org/10.1016/j. jseaes.2011.01.002

Mahler BJ, Lynch L, Bennett PC (1999) Mobile sediment in an urbanizing karst aquifer: implications for contaminant transport. Environ Geol 39:25-38

Mahler BJ, Personné JC, Lods GF, Drogue C (2000) Transport of free and particulate associated bacteria in karst. J Hydrol 238:179-193. https://doi.org/10.1016/S0022-1694(00)00324-3

Mahler BJ, Personné JC, Lynch FL, Van Metre PC (2004) Sediment and sediment-associated contaminant transport through karst. In: Studies of cave sediments. Springer, Boston, pp 23-46. https://doi.org/10. 1007/978-1-4419-911-8 2

Montgomery MA, Elimelech M (2007) Water and sanitation in developing countries: including health in the equation. Environ Sci Technol 41(1):17-24. https://doi.org/10.1021/es072435t

Nguyet VTM, Goldscheider N (2006a) Tracer tests, hydrochemical and microbiological investigations as a basis for groundwater protection in a remote tropical mountainous karst area, Vietnam. Hydrogeol J 14:1147-1159. https://doi.org/10.1007/s10040-006-0038-z

Nguyet VTM, Goldscheider N (2006b) A simplified methodology for mapping groundwater vulnerability and contaminant risk, and its first application in a tropical karst area, Vietnam. Hydrogeol J 14: 1666-1675. https://doi.org/10.1007/s10040-006-0069-5

Oberle P, Stoffel D, Walter D, Kahles G, Riester K, Nestmann F (2018) Implementierung innovativer Wasserförder- und -verteilkonzepte in einer Gebirgsregion im Norden Vietnams [Implementation of 
innovative water delivery and distribution concepts in a mountain region in ietnam]. Wasserwirtschaft 4:31-37

Pronk M, Goldscheider N, Zopfi J (2006) Dynamics and interaction of organic carbon, turbidity and bacteria in a karst aquifer system. Hydrogeol J 14:473-484. https://doi.org/10.1007/s10040-0050454-5

Pronk M, Goldscheider N, Zopfi J (2007) Particle-size distribution as indicator for fecal bacteria contamination of drinking water from karst springs. Environ Sci Technol 41:8400-8405. https://doi.org/ 10.1021/es071976f

Pronk M, Goldscheider N, Zopfi J, Zwahlen F (2009) Percolation and particle transport in the unsaturated zone of a karst aquifer. Ground Water 47:361-369

Reshes G, Vanounou S, Fishov I, Feingold M (2008) Cell shape dynamics in Escherichia coli. Biophys J 94:251-264. https://doi.org/10. 1529/biophysj.107.104398

Schillinger JE, Gannon JJ (1985) Bacterial adsorption and suspended particles in urban stormwater. J Water Pollut Control Federation 57(5):384-389

Schiperski F, Zirlewagen J, Hillebrand O, Licha T, Scheytt T (2015) Preliminary results on the dynamics of particles and their size distribution at a karst spring during snow melt. J Hydrol 524:326-332. https://doi.org/10.1016/j.jhydrol.2015.02.035

Schiperski F, Zirlewagen J, Scheytt T (2016) Transport and attenuation of particles of different density and surface charge: a karst aquifer field study. Environ Sci Technol 50:8028-8035. https://doi.org/10.1021/ acs.est.6b00335

Tam VT, Batelaan O (2011) A multi-analysis remote-sensing approach for mapping groundwater resources in the karstic Meo Vac Valley, Vietnam. Hydrogeol J 19:275-287. https://doi.org/10.1007/s10040010-0684-Z

Tran HT, Van Dang B, Ngo CK, Hoang QD, Nguyen QM (2013) Structural controls on the occurrence and morphology of karstified assemblages in northeastern Vietnam: a regional perspective.
Environ Earth Sci 70:511-520. https://doi.org/10.1007/s12665011-1057-1

Van Nguyen L, Nguyen NK, Van Hoang H, Tran TQ, Vu NT (2013) Characteristics of groundwater in karstic region in northeastern Vietnam. Environ Earth Sci 70:501-510. https://doi.org/10.1007/ s12665-012-1548-8

$\mathrm{Vu}$ VH, Merkel BJ (2019) Estimating groundwater recharge for Hanoi, Vietnam. Sci Total Environ 651:1047-1057. https://doi.org/10. 1016/j.scitotenv.2018.09.225

Walter D (2020) Wasserverteilungssysteme zur Umsetzung einer gerechten Verteilung eines limitierten Wasserdargebots [Water distribution systems for the implementation of a fair distribution of a limited water supply]. PhD Thesis, Karlsruhe Institute of Technology, Germany. https://doi.org/10.5445/IR/1000117534

WHO (2011) Guidelines for drinking-water quality, 4th edn. WHO, Geneva

Wilkinson K, Lead J (2007) Environmental colloids and particles: behaviour, separation and characterisation. IUPAC Series on Analytical and Physical Chemistry of Environmental Systems, 10, IUAPC, Research Triangle Park, NC

Zindler B, Stolpe H (2018) FuE-Verbundvorhaben KaWaTech: Vietnamesisch-Deutsche Kooperation zur Entwicklung nachhaltiger Technologien für die Karstwasserwirtschaft, Teilprojekt 7, Ländliche Entwicklung, Ressourcenschutz und soziokulturelle Aspekte [Joint R\&D project KaWaTech: Vietnamese-German cooperation for the development of sustainable technologies for karst water management, subproject 7, rural development, resource preservation and socio-cultural aspects]. Final report, Ruhr University Bochum, Instit. Environ. Eng. Ecol., Bochum, Germany. https://doi. org/10.2314/GBV:1015535372

Publisher's note Springer Nature remains neutral with regard to jurisdictional claims in published maps and institutional affiliations. 